\title{
Out of the Box Thoughts about the International Financial Architecture
}

Barry Eichengreen 


\title{
IMF Working Paper
}

\author{
Strategy, Policy, and Review Department \\ Out of the Box Thoughts about the International Financial Architecture \\ Prepared by Barry Eichengreen ${ }^{1}$ \\ Authorized for distribution by Tamim Bayoumi
}

May 2009

\section{This Working Paper should not be reported as representing the views of the IMF.}

The views expressed in this are those of the author(s) and do not necessarily represent those of the IMF or IMF policy. describe research in progress by the author(s) and are published to elicit comments and to further debate.

\begin{abstract}
The Global Credit Crisis of 2008-09 has underscored the urgency of reforming the international financial architecture. While a number of short-term reforms are already in train, this paper contemplates more ambitious reforms of the international financial architecture that might be implemented over the next ten years. It proposes routinizing the expansion of IMF quotas and the conduct of exchange rate surveillance. It contemplates an expanded role for the SDR in international transactions, which would require someone-like the IMF - to act as market maker. It considers proposals for reimposing Glass-Steagall-like restrictions on commercial and investment banking, something that will have to be coordinated internationally to be feasible. Other proposals would require banks to purchase capital insurance; here the question is who would be on the other side of the market. Again there is likely to be a role for the IMF. Then there are arguments for a new agency or institution to deal with cross-border bank insolvencies. Any such entity will require staff support, which might plausibly come from the Fund. Finally, some insist that international colleges of regulators are not enough - that it is desirable to create a World Financial Organization (WFO) with the power to sanction members whose national regulatory policies are not up to international standards. A WFO will similarly need staff support, of which the IMF would be one possible source. All this of course presupposes meaningful IMF governance reform so that the institution has the legitimacy and efficiency to assume these additional responsibilities. The paper therefore concludes with some conventional and unconventional proposals for IMF governance reform.
\end{abstract}

JEL Classification Numbers: F3

Keywords: International finance, financial architecture, IMF Author's E-Mail Address: eichengr@econ.berkeley.edu

\footnotetext{
${ }^{1}$ For comments I am grateful to Tam Bayoumi, Morris Goldstein, and Peter Kenen, who certainly should not be implicated in anything that follows.
} 


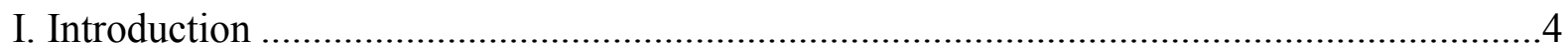

II. Eight Out Of The Box Ideas......................................................................................6

A. Countercyclical IMF Capital Charges.................................................................

B. A Price-Based Scarce Currency Clause ……………...............................................

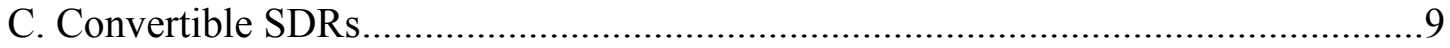

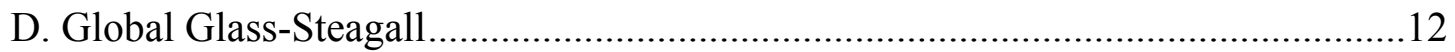

E. A Global Systemic Risk Facility .......................................................................13

F. A Multilateral Insolvency Trust for International Banks .........................................16

G. A World Financial Organization.........................................................................18

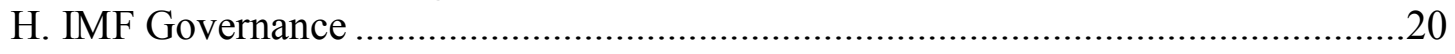

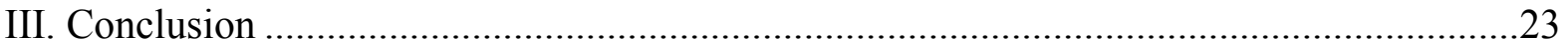




\section{INTRODUCTION}

The Global Credit Crisis of 2008-09 has underscored the urgency of reforming the international financial architecture. The consensus agenda starts with the need to strengthen the supervision and regulation of financial markets and institutions. It continues with the imperative of supporting demand while at the same time preventing the reemergence of global imbalance. It points to the importance of upgrading IMF surveillance and streamlining lending facilities. It is a reminder, if one was required, of the need to reconfigure seats and votes in the Fund to better reflect $21^{\text {st }}$ century realities. The gravity of the crisis implies that these reforms should be undertaken in months, not years.

But is this all that there is? This paper steps back and contemplates more ambitious reforms of the international financial architecture that might be implemented over the next ten years.

A first pair of proposals would routinize the expansion of IMF quotas and the conduct of exchange rate surveillance. Moving from quinquennial quota reviews to annual increases based on the growth of, inter alia, GDP would automatically increase IMF with resources with the expansion of the world economy. Overindexing would allow IMF capital charges to have the same countercyclical impact on global demand as overindexing bank capital charges to the growth of the loan book. Moving from the current approach to exchange rate surveillance to an automatic process under which countries in chronic surplus had to transfer a share of that surplus to the Fund would take staff out of the business of having to determine, using disputable metrics, whether a currency was fundamentally undervalued.

The crisis has also served as a reminder of the intrinsic instability of a financial system that utilizes a national unit as the international currency. The obvious reform is an expanded role for the SDR in international transactions of all kinds. But an expanded role for the SDR will require someone to act as market maker and subsidize bid-ask spreads until the market gains liquidity and depth. The obvious someone is the IMF.

Other potential medium-term reforms focus on financial markets and institutions. Some observers advocate the reimposition of Glass-Steagall-like restrictions on mixing deposittaking and payments-system functions with the riskier activities traditionally associated with investment banking. But moving back to something resembling Glass-Steagall will require international coordination or else banks in the country subject to the most stringent regulations may be competed out of business. The IMF is one candidate for orchestrating such coordination. Other proposals would require banks to purchase capital insurance to provide them with more resources in periods of systemic stress. Here the question is who would be on the other side of the market. Again there is likely to be a role for the IMF. Then there are arguments for a new agency or institution to deal with cross-border bank insolvencies. Any such entity will require staff support, which might plausibly come from the Fund. Finally, some insist that international colleges of regulators are not enough - that it is desirable to create a World Financial Organization with the power to sanction members whose national regulatory policies are not up to snuff. A WFO will similarly need staff support, whether in the form of FSAPs or something else. 
All this of course presupposes meaningful IMF governance reform so that the institution has the legitimacy and efficiency to assume these additional responsibilities. The paper therefore concludes with some conventional and unconventional proposals for IMF governance reform.

There is a good deal of conventional wisdom about what needs to be done to strengthen the international financial architecture in the wake of the Global Credit Crisis. Countries must upgrade their supervision and regulation of financial markets and institutions. They must support demand while at the same time avoiding the reemergence of global imbalances. The IMF should strengthen its surveillance of policies and markets in order to better anticipate systemic risks. It should streamline its procedures for disbursing resources. It should reconfigure its seats and votes to better reflect the economic and political realities of the $21^{\text {st }}$ century.

There is broad consensus on the desirability of these measures, though specifics are another matter. But there is also the question of whether these incremental changes are enough to make the world a significantly safer financial place. Aren't more radical reforms required? Shouldn't aspiring reformers set the bar higher?

The reality is that changes in the international financial architecture are almost always incremental. The membership of existing institutions is expanded rather than creating new institutions out of whole cloth. Regulations on the books are revised. Quota formulas are tweaked. Radical reform, like that at Bretton Woods in 1944, is the exception, not the rule.

The tendency to focus on marginal changes rather than throwing out the institutional inheritance and starting over reflects the fact that the public sector has already sunk significant costs in existing arrangements. The private sector has similarly sunk the costs of adapting to their existence. There would be high transactions costs of starting over. There is an obvious analogy with the history of technology, where it is argued that network technologies exhibit strong persistence. It makes little sense for any one agent to invest in radical improvements in technological practice when the payoff from such investments depends on whether or not others participating in the same network simultaneously make such investments. The existence of the network thus creates a coordination problem. ${ }^{2}$ And what is the international monetary and financial system if not a network of monetary and financial institutions and arrangements which displays a similar tendency toward lock-in? And what is the obstacle to radical reform if not a coordination problem?

At the same time, the history of technology also points to key moments when existing networks are disrupted, opening the door to radical change. ${ }^{3}$ If disruptions to the network are

\footnotetext{
${ }^{2}$ The Qwerty typewriter keyboard is only the most famous (and contested) illustration of the point. David (1985). See also Leibowitz, S. and Margolis, S. (1990).

${ }^{3}$ David speaks of "critical phases" where it may be possible to alter an established technological trajectory. See David (1991).
} 
sufficiently serious, everyone will move away from the existing equilibrium. Hopefully they will then coordinate on a preferable one.

Imagine that Global Credit Crisis is such a moment for the international financial arrangements. ${ }^{4}$ On what alternative equilibrium should participants in this system coordinate? To put it another way, what form would radical changes take?

What follow are eight out-of-the-box ideas. Some of these are even further out of the box than others. They fall under three headings: measures to buttress financial stability, steps to smooth the operation of the international monetary system, and reforms of the IMF. Admittedly, none of these ideas will be adopted in the short term. ${ }^{5}$ But they are the kind of things that policy makers should be pondering once they move beyond the current crisis.

\section{Eight Out OF The Box IdeAS}

\section{A. Countercyclical IMF Capital Charges}

It is widely recognized that the IMF's resources are inadequate for any new responsibilities that it might be thrust on the institution. As of early 2009, the Fund had some $\$ 200$ billion of quota resources, and could tap an additional \$53 billion through borrowing arrangements under the General Arrangements to Borrow (GAB) and New Arrangements to Borrow (NAB). ${ }^{6}$ At the G20 Summit in early April it was agreed to increase those resources by a further $\$ 500$ billion through, in the first instance, the New Arrangements to Borrow. ${ }^{7}$ At the time of writing, roughly half this amount has been promised by G20 leaders (some of which will still require approval by their national parliament or congress, as in the United States, in order for those promises to become reality). Whether the balance will be delivered, time will tell.

A more radical departure, which should be adopted in addition to and not instead of the above, would be to index countries' contributions to Fund resources and have them contribute annually. ${ }^{8}$ The goal might be to increase the IMF's real resources at an average

\footnotetext{
${ }^{4}$ It will be objected that the Asian crisis of 1997-98 was an equally devastating shock for the countries involved, but this led to only incremental, not radical reforms of the international financial architecture. To the extent that the current crisis is global and not merely regional, there is reason to think that, like the Great Depression of the 1930s, it might occasion more radical reforms.

${ }^{5}$ As I would be the first to acknowledge.

${ }^{6}$ By comparison, the new Short-Term Liquidity Facility (SLF), which allows applicants to draw up to 500 percent of quota, exposes it to potential claims of more than $\$ 450$ billion from 44 emerging market members alone.

${ }^{7}$ In addition, there was agreement in principle to authorize an additional $\$ 250$ billion of Special Drawing Rights, to be issued in proportion with countries' quota. These will not be resources for the IMF itself, strictly speaking, but for its members.

${ }^{8}$ Here regularization would require enabling legislation at the national level: the U.S. Congress for example would have to adopt legislation under which the U.S. would make annual contributions to the IMF based on
}

(continued...) 
annual rate of 3 percent, to reflect the 3 percent average real rate of growth of the global economy. ${ }^{9}$

A further innovation might be to make this additional capital charge countercyclical, in the same way that there is now increasing attention to the possibility of making bank capital ratios countercyclical. Thus, when global growth rises to 4 percent, countries might be asked to augment IMF real resources by 5 percent; when growth slips to 2 percent, they might be asked to augment IMF real resources by only 1 percent. ${ }^{10}$ In this way more budgetary resources would be freed up to support demand in bad times, while fewer budgetary resources would be available to further goose demand in good times.

A further step in the direction of routinization would be to index these capital charges to national growth rates rather than global growth rates. In this way the countercyclical impulse would be felt most strongly by the countries most in need of it. Votes in the Fund might be adjusted annually along with these contributions, the problem of fast-growing countries with chronically inadequate quotas and voting rights would be automatically addressed. The legitimacy of the IMF would be enhanced. ${ }^{11}$

\section{B. A Price-Based Scarce Currency Clause}

There have long been worries about asymmetric pressure to adjust felt by deficit and surplus countries - a problem that the Scarce Currency Clause (SSC) in the IMF's Articles of Agreement was designed to address. Recently discussions have focused on China and its chronic surpluses, though the point is more general. Authorizing other members to invoke the SCC against a country running chronic surpluses and to impose tariffs and other restrictions on its exports would be politically charged and difficult for the Executive Board. Reflecting the difficulties of doing so in a collegial institution, the SCC has never been invoked.

More efficacious in the long run would be to establish an automatic process that created incentives for surplus countries to adjust. A country that had run a current account surplus in

growth rates in GDP. Note that routinizing quota increases by indexing them to the rate of growth of countries' GDP would not address the current need to appreciably redistribute current quotas to better reflect $21^{\text {st }}$ century global economic realities. It would not correct the current imbalance between quotas and economic size but only prevent it from recurring in the future. A separate initiative - a one-time adjustment of quotas-would be needed to address the immediate problem.

${ }^{9}$ Actual contributions would be in nominal terms of course. Contributions would thus be calculated as, say, 3 percent of the outstanding subscription plus an adjustment for global inflation.

${ }^{10}$ This two-for-one formula would imply cutting contributions to zero when global growth fell to $1 \frac{1}{2}$ percent or less. Symmetry would then suggest capping contributions at 6 percent when global growth rose to $4 \frac{1}{2}$ percent or higher.

${ }^{11}$ It could conceivably be argued that this would be a disincentive to spurring growth. The same argument was offered in response to the issuance of GDP-indexed bonds, however, and proved exaggerated. It might be desirable to adjust votes to a moving average of past contributions rather than year by year so as not to penalize countries in recession or reward those experiencing an unsustainable boom. 
excess of 3 percent of GDP for three years, for example, might be required to transfer additional resources to the Fund at the end of every year in which that excess persisted. The transfer might equal one half of the current account surplus in excess of 3 percent of GDP. ${ }^{12}$ Alternatively, one can imagine a tax on the increase in foreign exchange reserves, when reserves had been increasing for 3 years and the increase in the current year exceeded 3 percent of GDP. ${ }^{13}$ Nothing would prevent countries from running large and persistent external surpluses if they found it difficult and costly to raise investment or reduce savings, but they doing so would entail an additional cost, in turn ratcheting up the pressure on the central bank and government to adopt policies of adjustment. ${ }^{14}$

Economists not liking tax schedules with discontinuities, one can imagine a tax on all increases in foreign reserves that started at infinitesimal levels but rose fairly quickly as the increase in reserves rose as a share of GDP and as a function of its persistence.

This approach would have the advantage that it would not be necessary for IMF staff or anyone else to decide whether a surplus country was "manipulating" its currency or whether that currency was "fundamentally undervalued." The country would not have to be cited as in violation of its obligations as an IMF member.

A tax on countries that undervalued their currencies to accumulate more reserves, requiring them to transfer dollars or the equivalent to the International Monetary Fund, could conceivably have the perverse effect of only encouraging them to undervalue their currencies by more so that they could replace the reserves that they had been forced by the provision to transfer to the Fund. In other words, the tax would have a relative price effect and an "income effect" working in opposite directions. The desire to accumulate reserves is only one reason, of course, why some countries are inclined to maintain highly competitive real exchange rates and run chronic external surpluses. Rodrik argues for example that so-called undervalued exchange rates are associated with rapid economic growth because they encourage manufacturing employment. ${ }^{15}$ To the extent that these other motives prevailed, the perverse "income effect" would not dominate. But to the extent that reserve accumulation pure and simple was the motivation, marrying the tax to other reforms designed to guarantee emergency liquidity to countries in need (expansion, for example, of the IMF's Flexible Credit Line) would weaken the motive and address the problem.

This tax could be written into the Articles of Agreement so that collecting it would not require, inter alia, a decision by the Executive Board. It would presumably be easiest to

\footnotetext{
${ }^{12}$ Or the charge might initially be set at a lower level and raised to, say, 50 percent over time (as members who wished to minimize it had more time to adjust).

${ }^{13}$ Or if it increased the average rate of growth of the economy in the last three years by a certain percent.

${ }^{14}$ Of course, if the goal is to encourage adjustment by surplus countries, nothing requires that the tax revenues be paid in to the Fund. They equally well might go to the World Bank for development assistance or the United Nations for peacekeeping operations.

${ }^{15}$ Rodrick (2008).
} 
implement in a period when it was not so obvious on which members it would predominantly fall. ${ }^{16}$

\section{Convertible SDRs}

In the 1950s and 1960s, Robert Triffin argued that an international monetary system in which a national currency serves is the dominant source of incremental foreign exchange reserves is intrinsically unstable. ${ }^{17}$ Reserves at that time predominantly took the form of gold and the dollar, but the supply of new monetary gold was relatively inelastic; therefore the dollar played the largest part on the margin.

Triffin argued that this was undesirable on a number of grounds. For one thing it allowed the United States to run a chronic balance of payments deficit, fund it at low cost, and live beyond its means. ${ }^{18}$ As a result, policy discipline in the United States was weakened. With other countries pegging their currencies to the dollar, the consequence was an inflationary bubble that infected the entire world economy.

In addition, as the world economy expanded, with other catch-up economies growing even faster that the United States, the official foreign dollar liabilities of the U.S. grew both as a share of global foreign exchange reserves and relative to the size of the U.S. economy. As those official foreign dollar liabilities grew large relative to U.S. gold reserves, confidence in the ability of the United States to convert them into gold at a fixed price was liable to weaken. The result might be disorderly exchange rate changes and credit stringency in the United States if foreign central banks scrambled out of dollar claims.

These observations gave rise in 1969 to the creation of Special Drawing Rights and in the 1970s to proposals for a Substitution Account through which SDRs could be substituted for dollar reserves. As Henry Wallach once noted, there were always two arguments for a Substitution Account, one being to "bail out the dollar from short-term difficulties" and the other to bring about a "long-term structural improvement in the world monetary system." ${ }^{19}$ In 2007 C. Fred Bergsten resuscitated the idea of a Substitution Account through which SDRs might be substituted for dollar reserves as a way of allowing central banks to diversify out of dollars without precipitating a dollar crash, which might undermine confidence in U.S. financial markets. ${ }^{20}$ This was a reincarnation of Wallich's first argument for the Substitution

\footnotetext{
${ }^{16}$ Tax compliance should probably not just be assumed. In the same way that the United States has been known to withhold its dues to the United Nations out of dissatisfaction with some of the organization's actions, one can imagine a country (a large country in particular) withholding its scarce-currency-clause tax payments to the IMF. A very strong international consensus (very strong peer pressure) would presumably be necessary to elicit compliance.

${ }^{17}$ See inter alia Triffin (1960).

${ }^{18}$ This being the "exorbitant privilege" of which Valery Giscard d'Estang complained.

${ }^{19}$ Wallich (1980).

${ }^{20}$ Bergsten (2007).
} 
Account - as a way of "bailing out the dollar from short-term difficulties." There was then a debate over whether such an initiative was necessary; in the event, there has been little evidence of central bank diversification out of dollars, at least as of the time of writing. ${ }^{21}$

The alternative is to rehabilitate Wallich's second argument of the need for an alternative to a national currency as international reserves as a way of smoothing the operation of the world monetary system. Assume, for simplicity, that strong network externalities/increasing returns result in a single instrument constituting the dominant share of reserves. ${ }^{22}$ Imagine that this is the dollar. This allows the United States to run chronic external deficits, finance them at low cost, and live beyond its means. It weakens policy discipline in the United States. It is conducive to the growth of a financial bubble in the U.S. capable of infecting the entire world. (This is one interpretation of the genesis of the Global Credit Crisis.) The commitment to convert dollars into gold (or into anything else, for that matter) is no longer there, but there continue to be warnings about a loss of confidence in the dollar with the expansion of the Fed's balance sheet and the prospect of massive fiscal stimulus to offset the effects of accumulated financial problems. We know that speculative attacks (in the sense of large numbers of traders simultaneously taking positions against a currency) are possible when currencies float and not only when they are fixed. In the longer run the question is what would prevent all this from happening again - whether it were the dollar and the United States or some other currency and economy in the privileged but vulnerable position. ${ }^{23}$

One answer is that such problems can be avoided by creating a composite unit that central banks find as attractive to hold as dollars and which could be used not just in transfers with the IMF itself and between IMF members (that is to say, governments). This general idea was proposed by People's Bank of China Governor Zhou Xiaochuan in the run-up to the G20 summit in London, on April 2.

But making the SDR an attractive unit in which to hold central bank reserves presupposes deep and liquid markets in SDR claims. Central banks use their reserves to smooth their countries' international transactions and to intervene in foreign exchange markets. They need

\footnotetext{
${ }^{21}$ There was also a debate over whether it was feasible (whether central banks would willingly hold SDR claims, given the instrument's limited liquidity) and whether it was equitable (given that someone, presumably the shareholders in the IMF, which assumed the dollar claims, would now bear the risk of capital losses in the event of dollar depreciation).

${ }^{22}$ An assumption about which I myself have doubts: Eichengreen (2006). But leave those doubts aside for sake of argument. See however the next footnote.

${ }^{23}$ Imagining a world of more than one reserve currency (most plausibly, the dollar and the euro) alters this logic only slightly. On the one hand, the economy issuing the reserve unit(s) is now larger relative to the world as a whole (it is the U.S. and Euro Area together, not just the U.S.). But the same problem as before- that the U.S. and Euro Area, the high-income countries with the most liquid markets, are likely to come to account for a shrinking share of the world economy over time, so that the demand for confidence-inspiring international reserves will grow faster than their capacity to supply them - continues to arise. In addition, there is the danger of sharp shifts in demand from one international currency to the other, since the two international units are likely to be close substitutes. Thus, while one source of fragility is less pressing in this alternative scenario, a second source of fragility is added.
} 
to buy and sell reserve assets without moving the markets or, for that matter, being noticed. This requires that the markets in which their reserve assets are traded be deep and liquid. Such liquidity does not spring up spontaneously. It requires a critical mass of SDR issuance, not only by the IMF itself but by other entities, such as governments, banks and nonfinancial firms, along with a critical mass of trading. In short, it requires commercializing the SDR.

There have been previous attempts to commercialize the SDR. A limited market in private SDRs emerged as early as 1975, when some banks began to accept time deposits in SDRs and some corporations began issuing long-term debt securities in SDRs. But these previous attempts were not especially successful. ${ }^{24}$ The coordination problem - that many prospective issuers were reluctant to issue SDR denominated claims in the absence of evidence that others were prepared to likewise-was substantial. The dollar's first-mover advantage proved impossible to overcome.

To be as attractive as dollar debt securities, SDRs would have to offer comparable liquidity and return. Historically, composite currencies traded commercially have not offered attractive combinations of liquidity and return. ${ }^{25}$ For this to happen, someone would have to act as market maker and subsidize the operation of the market until it acquired scale and liquidity.

The obvious someone is the IMF. It could stand ready to buy and sell SDRs at bid-ask spreads comparable to those in U.S. treasury and agency markets. It would be prepared to convert its SDR liabilities into any of the constituent currencies at those spreads. (Exchanging SDRs only into, say, dollars and asking market participants desiring another currency to pay the spread twice would not render the SDR particularly attractive or make it a true international currency.) Subsidies would have a cost, which members would have to agree to defray. They would presumably do so if they saw this as a worthwhile investment in reform of the international monetary system.

Transforming the SDR into a true international currency would require surmounting other hurdles. The IMF would have to be able to issue additional SDRs in periods of shortage, like the Fed provided dollar swaps to foreign central banks to ensure adequate dollar liquidity in the second half of 2008. At the moment, countries holding 85 percent of IMF voting power must agree before SDRs can be issued, which is no recipe for liquidity. IMF management would have to be empowered to decide on SDR issuance, just as the Federal Reserve can decide to offer currency swaps. For the SDR to become a true international currency, in other words, the IMF would have to become more like a global central bank and international lender of last resort.

\footnotetext{
${ }^{24}$ Sobol, (1981-82).

${ }^{25}$ See Allen (1993).
} 


\section{Global Glass-Steagall}

Any explanation for the Global Credit Crisis must confront the question: why the most serious banking crisis in 80 years, and why now? One answer runs as follows. ${ }^{26}$ There is a conflict between banks' core functions of providing a safe repository for household savings and operating the payments system, on the one hand, and the advantages of diversifying into originating, distributing and investing in risky assets, utilizing wholesale funding and employing leverage on the other. The second strategy offers economies of scale, scope and diversification but may undermine banks' ability to carry out their safe-repository and payments-system functions. ${ }^{27}$ Thus, the Global Credit Crisis resulted from deregulation that permitted banks to branch into new lines of risky business and that ratcheted up competitive pressure, which induced gambling to survive. That deregulation and intensification of competition occurred both at the national level, as with the elimination of Regulation Q and Glass-Steagall restrictions in the United States, and internationally, as capital controls were removed, restrictions on the activities of foreign banks were relaxed, and cross-border bank activity expanded. In the U.S., broker-dealers, no longer able to make a comfortable living off of fixed commissions on stock trades, moved into concocting and issuing new kinds of derivative securities and into employing additional leverage in their own investment strategies. In Europe, universal banks, feeling the intensification of cross-border competition, resorted to even more leverage than North American commercial banks. The result was serious financial vulnerabilities of the sort from which we are currently suffering.

One conceivable response would be to reimpose Glass-Steagall-like restrictions dividing the banking and financial system into two components. In one component (what we used to call commercial banking) liabilities would be limited to retail deposits, while assets would be limited to low-risk instruments: cash, short-term treasuries, commercial paper, adequatelycollateralized small business loans, and conforming mortgages. ${ }^{28}$ This would guarantee confidence in the security of deposits, reduce the likelihood of bank runs, and ensure the stability of the payments system. The other component of the system would be allowed to invest in riskier assets. Investment banks would provide loans to sub-investment-grade borrowers and take companies public. Hedge funds and mutual funds would invest in these

\footnotetext{
${ }^{26}$ Eichengreen, 2009.

${ }^{27}$ Although there is now an entirely predictable backlash according to which scale economies give way to scale diseconomies at a much lower level of activity than it was previously popular to argue. My own view is that economies of scale and scope exist, although there obviously comes a point where diseconomies set in. Consistent with this presumption is the observation that there had existed a noticeable tendency in the market for financial firms in the United States to attempt to exploit the existence of such economies of scope even before the formal removal of Glass-Steagall in 1999. Barth, Brumbaugh, and Wilcox (2000). See also Hu (2002). Historical studies similarly suggest that the imposition of Glass-Steagall raised the cost financial services: see Ramirez (1999). Whether the benefits in terms of greater efficiency that can be reaped over the relevant range dominate the costs in terms of greater scope for financial instability depends on how effectively one thinks the regulators can contain those instability effects. Recent experience clearly leads one to revise downward one's assessment of such effectiveness.

${ }^{28}$ As argued in Chamley and Kotlikov (2009). See also Bhide (2009), Johnson (2009), and Buiter (2009).
} 
same entities (both riskier financial and nonfinancial companies) and in their securities. Other changes would presumably be required to make this second segment tolerably safe: capital requirements, limits on the use of leverage, disclosure requirements, requirements that firms in this segment purchase financial disaster (capital) insurance (discusses further in Section E). Another way of putting the point is that, in contrast to traditional proposals for narrow banking, it still may not be the case that large entities in this second segment can be safely allowed to fail even if the payments system is secure. And if they are going to be rescued, they should be regulated before the fact.

What earlier proposals along these lines have failed to acknowledge is that in a financially integrated world such reforms will be feasible only if coordinated internationally. Otherwise, Icelandic banks will be allowed to take deposits from British savers and invest them in risky assets. British banks will complain that they are unable to compete, given harsh restrictions on their funding and investments, if foreign banks are free of such restrictions. To be both effective and politically acceptable, a new Glass-Steagall Act would have to be coordinated internationally. A relatively light-handed approach would be for such restrictions to be incorporated into the Basle Committee's Core Principles for Effective Banking Supervision. The IMF and World Bank could monitor compliance in their FSAP exercises. A more heavy handed approach would make them an obligation of IMF members.

Some would go only part way toward the reimposition of Glass-Steagall-style restrictions; UK FSA head Adair Turner, for example, would limit the range of activities that could be undertaken by any one financial institution without necessarily dividing these activities into two (ore more) mutually-exclusive groups. But even these somewhat less restrictive schemes would pose the same issues for international coordination. ${ }^{29}$

\section{E. A Global Systemic Risk Facility}

A number of authors, following Kashyap, Rajan and Stein, have suggested protecting against systemic risk by requiring banks to purchase capital insurance. ${ }^{30}$ Rather than holding additional capital at all points in time in order to protect against major shocks against which a bit of additional capital will be an inadequate buffer, they recommend that banks sell financial catastrophic (Cat) bonds, paying insurance premia whose cost is equivalent to a bit of additional capital in good times in return for a large payout in the event that systemic risk materializes. This will give them large amounts of protection when they need it as opposed to small amounts both when they do and when they don't. And since the payout on the policy is

\footnotetext{
${ }^{29}$ Precisely the same argument applies to proposals to prevent financial institutions from growing beyond a certain size (or to apply heavier capital requirements as they get larger) to limit the too-big-to-fail problem. Such capital requirements in one country would put its financial institutions at a competitive disadvantage internationally, assuming the existence of some scale or scope economies over the relevant range. Again it would be necessary to coordinate such measures internationally to make them palatable in any one country.

${ }^{30}$ Kashyap, Rajan, and Stein (2008), Nishimura (2008).
} 
indexed to a systemic rather than a bank-specific event, the moral hazard associated with the insurance will be limited. ${ }^{31}$

For this scheme to work there would have to be a counterparty prepared to put its own capital at risk. Put another way, for this scheme to be more attractive than self insurance, where each financial institution simply puts aside more capital on its own, the payoff in the event of the bad realization must be larger than what can be mobilized by liquidating the assets in which the banks' insurance premia have been invested. This is how Cat bonds issued to protect against earthquakes, floods and hurricanes work. The insured issues bonds that are purchased by investors (often hedge funds specializing in Cat bonds) using their own funds. Those investors receive an attractive return if the bad realization does not occur but lose part or all of their investment in the event it does. ${ }^{32}$

Cat bonds can be costly to issue because payoffs depend on rare events on which there may not exist reliable data, rendering the instrument difficult to value. ${ }^{33}$ Underwriters require issuers to pay substantial up-front costs for research on the distribution of risks and returns (geological surveys, weather studies) that investors require before committing their funds. The result is that small countries tend to be rationed out of this market. This same problem is likely to arise in the case of financial Cat bonds insofar as the risks affecting bank capital have similarly proven to be difficult to forecast on the basis of, inter alia, banks' internal models and regulators' indicators of impending distress.

Moral hazard can also be a problem in the same way that the availability of catastrophe insurance encourages homeowners to build in a flood plain; this is another factor potentially elevating costs. Any scheme for the provision of capital insurance should therefore be married to strengthened supervision and regulation to prevent additional risk taking.

Finally, opportunistic behavior can be a problem if the triggering event is reported or controlled by the insured. In principal this can be addressed by indexing the payoff to an independently verifiable indicator not under the control of the insured: wind speed, rainfall or

\footnotetext{
${ }^{31}$ A related scheme, due to Perotti and Suarez, envisages contingent liquidity rather than capital insurance. The problem, in this view, is not large losses leading to a hit to capital but temporary disruptions to market liquidity which hit banks relying on wholesale funding. Their scheme would require banks to pay a liquidity insurance premium to the central bank as a function of their reliance on wholesale funding (and also perhaps the tenor of that wholesale funding or the mismatch between the duration of their wholesale liabilities and assets). Banks would be discouraged from relying excessively on wholesale funding without being prohibited from resorting to it. The premium charges would compensate the central bank from having to provide emergency liquidity when market liquidity was disrupted. Unlike the capital insurance scheme, this would appear something that can be organized on the national level; there does not appear to be a prima facie case for international coordination orchestrated by the IMF or any other institution. See Perotti and Suarez (2009).

${ }^{32}$ Some Cat bonds include principal protected tranches, which guarantee the return of principal. In their case the triggering event affects payment of interest and the timing of the repayment of principal, which might be extended from, say, 3 to 10 years. One can imagine similarly applying this model to systemic-risk insurance.

${ }^{33}$ Another reason for the high premium demanded by investors is that there will be an incentive for the underwriter to retain its best risks while securitizing and selling off questionable ones.
} 
Richter Scale readings in the case of traditional Cat bonds, a global financial market indicator like the Ted spread or an index of bank shares in the case of financial Cat bonds. The problem here is basis risk (the Ted spread or an index of bank shares will be an imperfect indicator of capital needs), which renders insurance less effective (banks are paying for insurance that pays off at times other when the damage in question occurs). In addition the assumption that individual banks are too small to affect the Ted Spread or a global index of bank shares may be unrealistic. ${ }^{34}$

But Cat bonds can also be attractive to investors and therefore relatively inexpensive to issue insofar as returns are uncorrelated with those on other financial assets. They are attractive because they offer diversification, in other words. ${ }^{35}$ This is less likely to be true in the case of capital insurance, however. Returns to investors will decline in the event of systemic risk, which is precisely when the returns on their other investments will decline. It is not obvious therefore that financial Cat bonds will be attractive to hedge funds, pension funds, sovereign wealth funds, and sophisticated private investors.

A multilateral institution like the IMF could address these problems by creating a Global Systemic Risk Facility to underwrite systemic risk insurance for member countries. Similar countries facing similar risks, it could exploit the existence of economies of scale in the research needed at the underwriting stage. ${ }^{36}$ This is analogous to what the World Bank has done with its Caribbean Catastrophe Risk Insurance Facility: each of a number of Caribbean islands facing similar catastrophic risk pays a premium to underwrite the issuance of a common insurance instrument. ${ }^{37}$ In the present context the IMF could organize research on systemic risk and underwrite issuance of the standardized bond, perhaps in cooperation with one or more private reinsurers like Swiss Re or Munich Re. An entity like the IMF would also be in a position to reassure investors about moral hazard. For example, countries could be disqualified from receiving payouts and paying in further premia in the event of an FSAP that identified significant problems with its financial system. Measurement of the parametric trigger should presumably be delegated to an independent agency following transparent rules. ${ }^{38}$

Insofar as systemic risk hits different countries at different times or with different degrees of severity, payouts would not have to be uniform across countries. What we might call the IMF

\footnotetext{
${ }^{34}$ Can you say "Lehman Brothers?"

35 This is one explanation for why the market in Cat bonds has held up relatively well despite the severity of the credit crisis - in contrast to the markets in other complex financial instruments.

${ }^{36}$ Since the Fund is not profit oriented this would presumably also address the fear that the underwriter, enjoying private information, was retaining the best risks while selling off the others (see above).

${ }^{37}$ Guesquite and others (2008).

${ }^{38}$ Given the IMF's politicized nature, this would be a function that the institution presumably would want to outsource. Just for fun, one is tempted to say "to the rating agencies." An alternative is to address the politicization of IMF decision making. (See Section H).
} 
Systemic Risk Facility could thus act as a risk aggregator. It would allow countries to pool their country-specific risks into a diversified portfolio, allowing for a substantial reduction in premium costs relative to a situation where a capital-insurance scheme was pursued at the country level. Even in the current Global Credit Crisis, systemic risk and losses of bank capital have not affected all countries to the same extent.

Just why institutional and individual investors can't do the pooling themselves is not exactly clear. ${ }^{39}$ One possibility is that effective diversification is possible only when the bonds in question are issued by a range of different countries but the "After you, Alphonse" problem prevents anyone from going first. If this is the case, then a global scheme organized by an entity like the IMF is an appropriate solution. (In this instance it would be necessary for the IMF to provide the impetus but not the finance.) Similarly, if there would be a tendency for countries to under-invest in systemic risk insurance because some of the costs of disruptions to the national financial system are incurred by other countries, then an IMF initiative to coordinate investments in insurance would be the appropriate way of internalizing this externality. ${ }^{40}$

The details of this scheme would still have to be fleshed out. ${ }^{41}$ Would the insurance premia be paid by banks directly to the IMF, which in the event of a systemic crisis would see that the payout went directly to those same banks? If so, which banks, and who would decide? Or would the premia be paid to the IMF by the bank regulator in the member country, which would make the decision on which banks participated, collect the premia from them, and distribute the payoff on receiving it from the Fund?

\section{F. A Multilateral Insolvency Trust for International Banks}

A gap in the international financial architecture pointed up by the crisis is the absence of a regime to deal with the insolvency of a major bank or bank-like institution doing business in multiple countries. International insolvencies, to the extent that they are managed, are managed by separate national insolvency regimes, each of which appoints a fiduciary (or trustee or administrator) to assume control of the firm and its assets, value and prioritize creditor claims, and reorganize or liquidate the firm so as to ensure that those claims are respected. But fiduciaries of different nationality see their priorities differently. Consistency will be difficult if different fiduciaries, following national practice, attach different weight to preserving economic value versus settling claims. A potentially viable enterprise may be driven out of business as a going concern if fiduciaries scramble for assets. Creditors may be

\footnotetext{
${ }^{39}$ The success of entities like the World Bank's Caribbean facility suggests that there are, in fact, occasions where private investors do not themselves undertake these functions but become enthusiastic investors when someone else does the aggregation.

${ }^{40}$ The other explanation for the absence of a private market - that individual country risks can become highly correlated in a systemic crisis and the counterparties who have bought the bonds default on their obligations under these extreme circumstances - points to a less reassuring interpretation.

${ }^{41}$ As with all the other schemes in this paper.
} 
treated unfairly if assets can be allocated by multiple fiduciaries. These difficulties are illustrated by the case of Lehman Bros. with its operations in both the U.S. and UK.

There has been some progress in encouraging cooperation among trustees and national judicial systems. The International Association of Restructuring, Insolvency and Bankruptcy Professionals (INSOL International), Committee $\mathrm{J}$ of the International Bar Association, and UNCITRAL (the United National Commission on International Trade Law) have all commissioned working papers, organized international meetings and established working groups to encourage informal cooperation, foster the recognition of foreign insolvency proceedings, and promote the adoption of model legislation. Financial firms have sought to promote the standardization of contract terms in different countries so that enforcement can be similarly standardized in insolvency proceedings. Examples of this are the International Foreign Exchange Master Agreement (IFEMA) and International Swaps and Derivatives Association Master Agreement (ISDA Agreement). In a limited number of cases, countries have negotiated bilateral treaties and conventions about how to cooperate in this process.

The argument that cooperation among national forums is neither reliable nor efficient leads to suggestions that international insolvency proceedings should occur in a single forum, which would reach all assets of the debtor, wherever located, and distribute those assets to all creditors, wherever located. The name for this approach to international insolvency is "universalism." 42 But in practice it is not obvious in what single national jurisdiction universal proceedings should take place. The one where the financial entity was first licensed, or the one where it has the most assets? It is not clear whether the legal authorities in that jurisdiction can be counted on to fairly distribute assets to creditors located in other countries.

These observations create an argument for a universal venue where cross-border insolvencies of internationally-active financial institutions can be administered. One can imagine an International Court of Insolvency comparable to the International Court of Justice, headed by experienced jurists who would in turn appoint respected, neutral administrators. Their actions would have to be guided by international law, build presumably on the UCITRAL's Model Law on Cross-Border Insolvency. That insolvency proceedings for internationally active banks would fall under their jurisdiction could be made an obligation of IMF members. This obligation would still, of course, have to be given the force of law in each individual country through the passage of the relevant law. And the international court will need staff support to gather necessary data on assets and liabilities and other information needed for restructuring and reorganization; this would presumably be provided by national regulators, whose efforts could be coordinated by the IMF. ${ }^{43}$

\footnotetext{
${ }^{42}$ Buxbaum (2000).

${ }^{43}$ Readers will be reminded of the debate over the viability of and need for an international insolvency regime or court for sovereign debtors; see Raffer (2005).
} 


\section{G. A World Financial Organization}

The preceding has provided multiple examples of how problems arising in connection with supervision and regulation in one country can infect financial systems in other countries. Recent experience suggests that even small countries can be the source of significant spillovers. ${ }^{44}$ Yet mechanisms for ensuring that national decisions regarding regulation are taken with external as well as domestic consequences in mind remain inadequate. Efforts to share information, apply peer pressure, and correct regulatory problems through the deliberations of the Financial Stability Forum, the Basel Committee on Banking Supervision and colleges of supervisors (as agreed to by the G7 in April 2008) have been shown by the recent crisis to not be up to the task. ${ }^{45}$ International standards for supervision and regulation have not been sufficiently demanding. Compliance with such standards as exist has been spotty, since there exist no international sanctions on countries failing to comply.

The latest idea for strengthening existing arrangements would have the Financial Stability Forum define acceptable practice and the IMF assess whether national regulation meets that standard. But is the Financial Stability Forum sufficiently legitimate and accountable, even given its recently expanded membership? ${ }^{46}$ Does the Forum have adequate staff? Is the IMF, for its part, willing to take on its large shareholders when their national practices are not up to snuff?

An alternative would be to create a World Financial Organization analogous to the alreadyexisting World Trade Organization (WTO) ${ }^{47}$ In the same way that the WTO establishes a principles for trade policy (nondiscrimination, reciprocity, transparency, binding and enforceable commitments) without specifying outcomes, the WFO would establish principles for prudential supervision (capital and liquidity requirements, limits on portfolio concentrations and connected lending, adequacy of risk measurement systems and internal

\footnotetext{
${ }^{44}$ Consider the cases of Iceland and Ireland, for example.

${ }^{45}$ For good theoretical reasons, argue a number of recent authors. Thus, Holthausen and Ronde (2005) show that cooperating supervisors will not in general reveal all relevant information if their interests to not perfectly coincide. Feeixas (2003) shows that information asymmetries will in general not lead to optimal supervision in the absence of a centralized process or an enforcement mechanism that produces its functional equivalent.

${ }^{46}$ At its plenary meeting in London on March 11-12, 2009, the FSF agreed to broaden its membership to add Argentina, Brazil, China, India, Indonesia, Korea, Mexico, Russia, Saudi Arabia, South Africa, and Turkey (the remaining members of the G20) along with Spain and the EU. This decision was confirmed by G20 leaders at their London Summit on April 2, when they announced that the FSF would be renamed the Financial Stability Board.

${ }^{47}$ Eichengreen (2008). In a similar proposal, Claessens (2008) has proposed creating an international charter for banks engaged in cross-border activity. Internationally active banks would be required to secure a charter from an international College of Supervisors and be subject to its supervision. When the members of the College determined that a bank was in violation of its charter, it could impose cease-and-desist orders, limit the operations of said institutions, and require remedial action.
} 
controls) and without attempting to prescribe the structure of regulation in detail. ${ }^{48}$ The WFO would define obligations for its members; the latter would be obliged to meet international standards for supervision and regulation of their financial markets and institutions. Membership would be obligatory for all countries seeking freedom of access to foreign markets for domestically-chartered financial institutions. ${ }^{49}$ The WFO would appoint independent panels of experts to determine whether countries were in compliance with those obligations. Importantly, it would authorize the imposition of sanctions against countries that failed to comply. Other members would be within their rights to restrict the ability of banks and nonbank financial institutions chartered in the offending country to do business in their markets. This would provide a real incentive to comply.

It will be objected that national governments would never let an international organization dictate their domestic regulatory policies. The rebuttal is that the WFO would not dictate. The specifics of implementation would be left to the individual country. Members would still be able to tailor supervision and regulation to the particularities of their financial markets. But those regulatory specifics would have to comply with the broad principles set down in the WFO charter and associated obligations.

We already do the equivalent for trade. Dispute settlement panels already determine whether, inter alia, U.S. tariffs on timber imports from Canada are in compliance with U.S. WTO obligations. If not, we have the choice of whether to change those laws or face sanctions and retaliation. If the U.S. and other countries accept this in the case of trade, why should they not accept it for finance? ${ }^{50}$

Who would have the power to initiate cases under this WFO model? WTO cases are initiated by a country that feels it has been injured by foreign trade policies. One can imagine instance of this in the context of finance (other European countries objecting to Ireland's blanket deposit guarantees or Icelandic banks' offshore deposit-taking activities). But more generally, in the case of finance, injury is likely to be more diffuse; the adverse financial repercussions are likely to be more widespread. And given the speed with which such markets work, it is even more important to correct problems before the fact.

The alternative would be for cases to be initiated at the volition of the WFO's panel of independent experts, who might choose to convene a panel in response to an ambiguous FSAP. The advantage of this approach over the FSF-IMF model is that it would not be necessary to imagine that the Fund could provide an up-or-down decision on the adequacy of

\footnotetext{
${ }^{48}$ The Basel Core Principles for Effective Banking Supervision would be the obvious place to go when defining these principles.

${ }^{49}$ The move to a WFO would presumably occur after some years of satisfactory experience with a GATT-like predecessor (if the history of the WTO is any guide).

${ }^{50}$ One answer is that in certain countries, such as my own, finance is more powerful than industry as a source of political funding. Another is that financial intermediation is more complex and opaque than bananas, rendering governments less sure about the consequences of delegating authority over finance than trade.
} 
national regulation; the "rating decision" would be outsourced to the independent panel of experts.

The alternative, of course, would be to make the IMF itself more independent, a possibility to which I now turn.

\section{H. IMF Governance}

There is a broad consensus regarding what should be done to reform the governance of the IMF in order to enhance its legitimacy and accountability. ${ }^{51}$ Quotas need further revision to give fast-growing countries louder voice and to otherwise reflect the realities of the $21^{\text {st }}$ century. The 85 percent supermajority for substantial changes to the Articles of Agreement, new SDR issues and the like need to be relaxed (perhaps to 80 percent) so that no one country exercises a veto over key policy decisions and reforms. Voting procedures within the institution should be revised to better balance the interests of large and small countries. The Executive Board needs to be updated to better reflect the economic and political realities of the $21^{\text {st }}$ century and downsized, perhaps to 20 members, to streamline decision making and allow for more emerging-market representation, something that can be most easily accomplished if the EU or even the euro area moves to a single chair. The leadership selection process needs to be opened up once and for all. The International Monetary and Financial Committee of 24 finance ministers from leading countries should be transformed into a Council, as envisaged by the Article XII of the Articles of Agreement. The Council would then provide oversight of the Executive Board and its decisions through periodic meetings and which could be canvassed regularly for its views of major issues through a written procedure.

A few moments of reflection are enough to convince one that many of the fashionable items on this menu have more symbolic than operational value. Virtually all important operational decisions are made on the basis of consensus, not votes. It can be argued that consensus is formed in the shadow of the voting rules, but even then careful observers of the Fund have noted that the ability of a member's representative to present his arguments articulately and forcefully can shape board decisions above and beyond what one might expect on the basis of his voting share. Even if the supermajority requirement was brought down from 85 to 80 percent, it is hard to imagine that the United States, with its 17 percent of total votes, could not round up a few allies with 3 percent of total votes between them to tip the balance. One can reasonably question whether decision making would be significantly streamlined by downsizing the Executive Board to "only" 20 members. Finally, one can ask whether changing the name of the IMFC to the IMF Council and having the latter meet biannually would significantly alter decision making by a Board that works full time at absorbing staff reports and other documents and meets up to four days a week. ${ }^{52}$

\footnotetext{
${ }^{51}$ For a clear statement of this conventional wisdom see Center for International Governance and Innovation (2009).

${ }^{52}$ Another argument for simply changing the name of the IMFC to IMF Council is that IMFC is also the name of a Dutch hedge fund administrator and trustee....
} 
More substantial reform would start with abolishing the Executive Board. Day-to-day decisions would be made by a majority vote of the managing director and deputy managing directors in the manner of a monetary policy committee of a central bank. These individuals would have the independence and autonomy to act quickly and take politically difficult decisions, such as, inter alia, publicly criticizing the exchange rate or fiscal policy of a large member or disbursing a large amount of money quickly. ${ }^{53}$ They would not be slowed down by first having to obtain the approval of 24 mid-level bureaucrats, some of whom take instructions directly from the governments of those same large members. They would not be hindered in adopting radical departures from past policies, as required by radically new circumstances, by a large board representing a large collection of countries that, by its nature, is slow to accept modifications of past practice.

Everyone agrees what is needed to make the IMF more effective. The Fund needs to strengthen its surveillance of policies and markets and come clean when it perceives potential threats to national and global financial stability. It needs to be able to provide large amounts of emergency liquidity quickly when circumstances require. Modernizing the current 1940s-vintage structure to create an independent management team would allow the latter to move with the speed and flexibility of a modern central bank monetary policy committee confronted with serious regulatory problems and financial instability - something that is not true of present arrangements, which require it to first obtain the approval of the members of a large and heterogeneous Executive Board that must in turn obtain the approval of their political masters.

But for such strong independence to be politically acceptable, the members of the management team would be equally strongly accountable for their actions. They would have to be more transparent about their decisions and their criteria for taking them. One could imagine delayed publication of minutes of their deliberations. ${ }^{54}$ Alternatively, the Managing Director could hold regular press conferences summarizing the management team's decisions in the manner of the ECB. It might be necessary to relax the informal rule that IMF management does not appear before congressional/parliamentary committees.

Most importantly, management would have to be strongly accountable to the IMFC/Council in the same manner that the president and monetary policy committee of a central bank are accountable to their national parliament or congress. They would have to be required to justify their actions to the IMFC. They should be subject to a formal vote of no confidence. The management team would be not just more independent but also more accountable. The IMFC, for its part, would be accountable to the Board of Governors of the IMF. ${ }^{55}$ It should be reconstitute as the IMF Council so that what are now recommendations become binding

\footnotetext{
${ }^{53}$ To provide insulation from political pressures, members of the management team would have to be appointed/elected to long terms in office.

${ }^{54}$ In the manner of the Fed. This would be a small step technically, since minutes of Board meetings are already kept and a highly sanitized version is published as the conclusions of the chair.

${ }^{55}$ Readers will recognize the echoes of DeGregorio and others (1999) but also King (2006).
} 
instruments to management, as provided for under the Articles of Agreement. There could be a commitment that by its members to meet at least quarterly.

It would of course be necessary to do more than simply abolish the Executive Board. The convention that the managing director should be a European and his first deputy an American would have to be abolished and leadership selection structured so as to reward the most qualified candidates. ${ }^{56}$ It would be necessary to devise a selection mechanism for the entire management team that both picked out high-quality candidates and ensured a reasonable degree of geographic and economic diversity. ${ }^{57}$

The most compelling objection to schemes of this sort is that the decisions of the IMF are more complex and therefore entail more discretion than those of a central bank and that they require the Fund to put taxpayer money more directly at risk. Since a central bank just sets interest rates rather than applying detailed prescriptions for changes in the fabric of social and economic policy, it is said, independence for its monetary policy committee is politically tolerable. Since it just sets interest rates, an action which is easily monitored and assessed, holding its independent management accountable for their actions is relatively straightforward. And since central banks accept only high-quality collateral in their lending operations, they do not put serious taxpayer money at risk (typically, in contrast, they are a profit center).

In the wake of the credit crisis of 2008-09. it is clear that none of these objections hold water. We have seen national central banks engage in very detailed interventions in financial and other markets. They have purchased all manner of collateral as required by policies of credit easing, exposing themselves to significant balance-sheet losses. The reality is that modern central banks, not unlike the IMF, are required to do much more than just set interest rates. This has created some discomfort among observers and demands that central bankers do a better job at justifying their actions; it has similarly created pressure that mechanisms for holding them accountable, be these oversight committees of or appointed by the U.S. Congress or the relevant committees of the European Parliament, be strengthened. But it has not given rise to the view that central bank independence is intolerable or, for that matter, undesirable.

\footnotetext{
${ }^{56}$ As G20 finance ministers reportedly agreed at their mid-March 2009 meeting in Sussex, England.

${ }^{57}$ This part of the problem is not straightforward. Competing five-person slates of one North American, one Latin American, one African, one Asian and one European candidate could be nominated (a slight expansion of the present four person managing director-deputy managing director team), and the entire slate could be voted on by the Board of Governors. This would not be optimal, since governors might be forced to vote for slate members for whom they had little desire in order to secure the election of other slate member. An alternative would be to have five regional candidates elected by the countries of the five respective regions; there would then be a second election in which the entire membership voted on who among the five winners they preferred as managing director. Or candidates could be nominated and voted for without reference to nationality/national origin, with the candidate receiving the most votes becoming MD and the next four becoming her deputies, the assumption that the need for regional diversity would take care of itself. Solving this problem can only be done by a better political scientist than the present author.
} 


\section{CONCLUSION}

None of these blue-sky ideas will come to fruition overnight. But in the meantime there is plenty of a more straightforward nature to do. The IMF can push ahead once shareholders recover their appetite for so doing with the reform of quotas and with reconstituting and streamlining the Executive Board. It can transform the IMFC into a Council that can issue binding instructions to management and the board. It can entice additional countries, Asian countries in particular, to sign up for its short-term liquidity problem, eliminating the stigma problem once and for all. It can make Financial Sector Assessment Programs mandatory rather than at the volition of the member. It can administer FSAPs at the regional rather than the national level, first in Europe and then other parts of the world, not least in order to be sure that FSAP exercises encompass banks' overseas subsidiaries and affiliates. These may all be "in the box" initiatives but they are no less important and valuable for the fact.

At the same time, the existence of this "in the box" agenda should not be an excuse for failing to engage in out-of-the-box thinking.

For out-of-the-box ideas to have legs, they must be accompanied by a roadmap for how to get from here to there in the space of, say, ten years. It is clear that reform of IMF governance is a prerequisite for many of the other ambitious ideas entailing a role for the Fund. Without meaningful governance reform, emerging market members would not agree to a significant expansion of the Fund's resources along the lines of the indexing scheme in the first section above. They would not agree to an automatic system of contributions, overseen by the Fund, from countries in chronic balance of payments surplus. They would not acquiesce to the IMF acting as secretariat to a World Financial Organization or even to the latter using FSAPs as the basis for its decisions. They would not agree that the IMF should be the source of staff support to the International Court of Insolvency. They would not agree to having the Fund pool and underwrite subscriptions to a Capital Insurance Facility or coordinate the move to a Global Glass-Steagall Act. They would not look favorably on efforts by the Fund to enhance the role of the SDR. Thus, progress on the other out-of-thebox ideas offered here hinges on prior governance reform.

This suggests a sequencing strategy. First, pursue business as usual—strengthening the FSAP process, streamlining the SLF. Next, proceed meaning governance reform, starting with the conventional agenda and then proceeding to the more ambitious reforms enumerated here. Finally, leverage the enhanced legitimacy and efficiency resulting from those governance reforms to implement the remaining items on the agenda. Were all or even many of the proposals enumerated here to be implemented in this manner, the result would be a safer financial world. 


\section{References}

Allen, Reynolds, 1993, "Composite Currencies: SDRs and ECUs," Open Economies Review 4, pp. 97-110.

Barth, James, Dan Brumbaugh, and James Wilcox, 2000, “The Repeal of Glass-Steagall and the Advent of Broad Banking," Journal of Economic Perspectives.

Bergsten, C. Fred, 2007, "How to Solve the Problem of the Dollar," Financial Times, December 11.

Bhide, Amar, 2009, “In Praise of More Primitive Finance," The Economist's Voice, 6: 3, February.

Buiter, Willem, 2009, "Regulating the New Financial Sector,” Vox EU, March 9.

Buxbaum, Hannah L., 2000, "Rethinking International Insolvency: The Neglected Role of Choice-of-Law Rules and Theory," Stanford Journal of International Law, 36, pp. 23-71.

Center for International Governance and Innovation, 2009, "Advancing the Reform Agenda: A Proposal to the G-20 on International Financial Institution Reform" (University of Waterloo), February 23.

Chamley, Christophe and Lawrence Kotlikoff, 2009, "Limited Purpose Banking: Putting an End to Financial Crises," unpublished manuscript, Boston University, January.

Claessens, Stijn, 2008, “The New International Financial Architecture Requires Better Governance" in What G20 Leaders Must Do to Stabilize our Economy and Fix the Financial System, ed. by Barry Eichengreen and Richard Baldwin, VoxEU, November 11.

David, Paul, 1985, "Clio and the Economics of Qwerty," American Economic Review Papers and Proceedings, pp. 332-337.

David, Paul, 1991, "The Hero and the Herd in Technological History: Reflections on Thomas Edison and the Battle of the Systems" in Favorites to Fortune, ed. by Patrice Higonnet, David Landes and Henry Rosovsky, (Harvard University Press), pp. 72-119.

DeGregorio, Jose, Barry Eichengreen, Takatoshi Ito, and Charles Wyplosz, 1999, An Independent and Accountable IMF, (Centre for Economic Policy Research 1999).

Eichengreen, Barry, 2006, “Sterling's Past, Dollar's Future," in Global Imbalances and the Lessons of Bretton Woods, (MIT Press).

Eichengreen, Barry, 2008, "Not a New Bretton Woods but a New Bretton Woods Process," in What G20 Leaders Must Do to Stabilize our Economy and Fix the Financial System, ed. by Barry Eichengreen and Richard Baldwin, VoxEU, November 11. 
Eichengreen, Barry, 2009, "Origins and Responses to the Current Crisis," CESifo Forum, November, pp. 6-11.

Freixas, Xavier, 2003, “Crisis Management in Europe," in Financial Supervision in Europe, ed. by J.J.M. Kremers, Dirk Schoenmaker, and P.J. Wierts, (Edward Elgar, 2003), pp. $102-119$.

Guesquire, Francis, 2008, "Caribbean Catastrophe Risk Insurance Facility: A Solution to the Short-Term Liquidity Needs of Small Island States in the Aftermath of Natural Disasters" (World Bank).

Holthausen, Cornelia, and Thomas Ronde, 2005, "Cooperation in International Banking Supervision,” CEPR Discussion Paper No. 4990 (London: Centre for Economic Policy Research).

$\mathrm{Hu}$, Lei, 2002, “On the Wealth and Risk Effect of the Glass-Steagall Overhaul: Evidence from the Stock Market," unpublished manuscript, University of Notre Dame.

Johnson, Simon, 2009, "High Noon: Geithner vs. the Oligarchs," www.growthcommissionblog.org, February 9.

Kashyap, Anil Raghuram Rajan, and Jeremy Stein, 2008, "Rethinking Capital Regulation," paper presented to the Jackson Hole Symposium of the Kansas City Fed, August.

King, Mervyn, 2006, "Reform of the International Monetary Fund," speech to the Indian Council for Research on International Economic Relations, Delhi, February 20, www.bankofengland.co.uk.

Leibowitz, Stanley and Stephen Margolis, 1990, “The Fable of the Keys," Journal of Law and Economics, 33, pp. 1-26.

Nishimura, Kiyohiko, 2008, “A Proposal for Public Capital Insurance,” unpublished manuscript; Bank of Japan, November 22.

Perotti, Enrico and Javier Suarez, 2009, "Liquidity Insurance for Systemic Crises," www.ft.com, February 24.

Raffer, Kunibert, 2005, "Considerations for Designing International Insolvency Procedures," Journal of Law, Social Development and Justice, 1.

Ramirez, Carlos, 1999, "Did Glass Steagall Increase the Cost of External Finance for Investment? Evidence from Bank and Insurance Company Affiliations," Journal of Economic History, 59, pp. 372-396.

Rodrik, Dani, 2008, “The Real Exchange Rate and Economic Growth,” Brookings Papers on Economic Activity, Fall, pp. 365-412. 
Sobol, Dorothy, 1981-82, "The SDR in Private International Finance," Federal Reserve Bank of New York Quarterly Review, Winter, pp. 29-41.

Triffin, Robert, 1960, Gold and the Dollar Crisis, (Yale University Press).

Wallich, Henry, 1980, "The World Monetary System after the Postponement of the Substitution Account," Intereconomics, July/August, pp. 163-167. 